\title{
Ultrastructure of the mandibular glands of eusocial bees: a comparative study.
}

\author{
L.F. Gracioli ${ }^{1}$, R.L.M. Silva de Moraes $^{1}$, C. da Cruz-Landim ${ }^{1}$. \\ ${ }^{1}$ Departamento de Biologia, Instituto de Biociências, UNESP - Av. 24A, n 1515. CEP 13506-900, \\ Rio Claro, SP, Brazil.
}

The mandibular glands are paired structures localized in the head of the bees, oppenig in the base of the mandibles. The secretory cells of these glands belongs to the class III of Noirot and Quennedey [1]. In Apis mellifera the secretory cells covers all the reservoir and in workers are related with the production of of alarm pheromones and in queens with sexual pheromones, besides other functions. In Melipona bicolor, one of the rare species of bees that presents natural polygyny, the worker's and the queen's mandibular glands are formed by a group of secretory cells separated of the reservoir, such a cells produce pheromones which seem to have participation in the interactions between workers and queens during the provision and oviposition processes (POP). In Scaptotrigona postica, the gland present a bifid reservoir, being just one of the branch totally covered by secretory cells, being the secretion in workers used as trail pheromone. In queens its function is still unknown. The aim of this investigation is to compare the gland ultrastructure among these three species, whose social organization presents some particularities: A. mellifera only accepts the presence of one queen for colony, be the queen virgin or fecundated; M. bicolor accepts more than one physogastric queen and $S$. postica accepts virgin queens. The glands of these species were fixed and prepared for transmission electronic microscopic analyses by routine procedures. According to the results, the mandibular glands of all species are constituted by secretory cells of the class III of Noirot and Quennedey [1]. Each cell connects to the reservoir through a canalicule (Fig. 1B,C), which presents a portion surrounded by the secretory cell and, other that, continues extracellularly with other canalicule, which oppenig and realizing the secretion in the reservoir's lumen. In all these species, the secretion is of lipidic nature, although its composition may vary. In this way, the cytoplasm of the secretory cells has indicatives of its involvement with the lipidic synthesis, as very well developed smooth endoplasmatic reticule (Fig.1A,D), lipidic droplets (Fig. 1D) and myelinics bodies (Fig. 1B). In M. bicolor, the characteristic feature of the mitocondria (Fig. 1A) suggests that these organelas also may participate in secretion production. The great amount of myelinics bodies in the cytoplasm of the secretory cells may be related with hidrocarbon production.

\section{Reference}

[1] Noirot and Quennedey, Annls. Soc. Ent. Fr. 27 (1991) 123-128. 


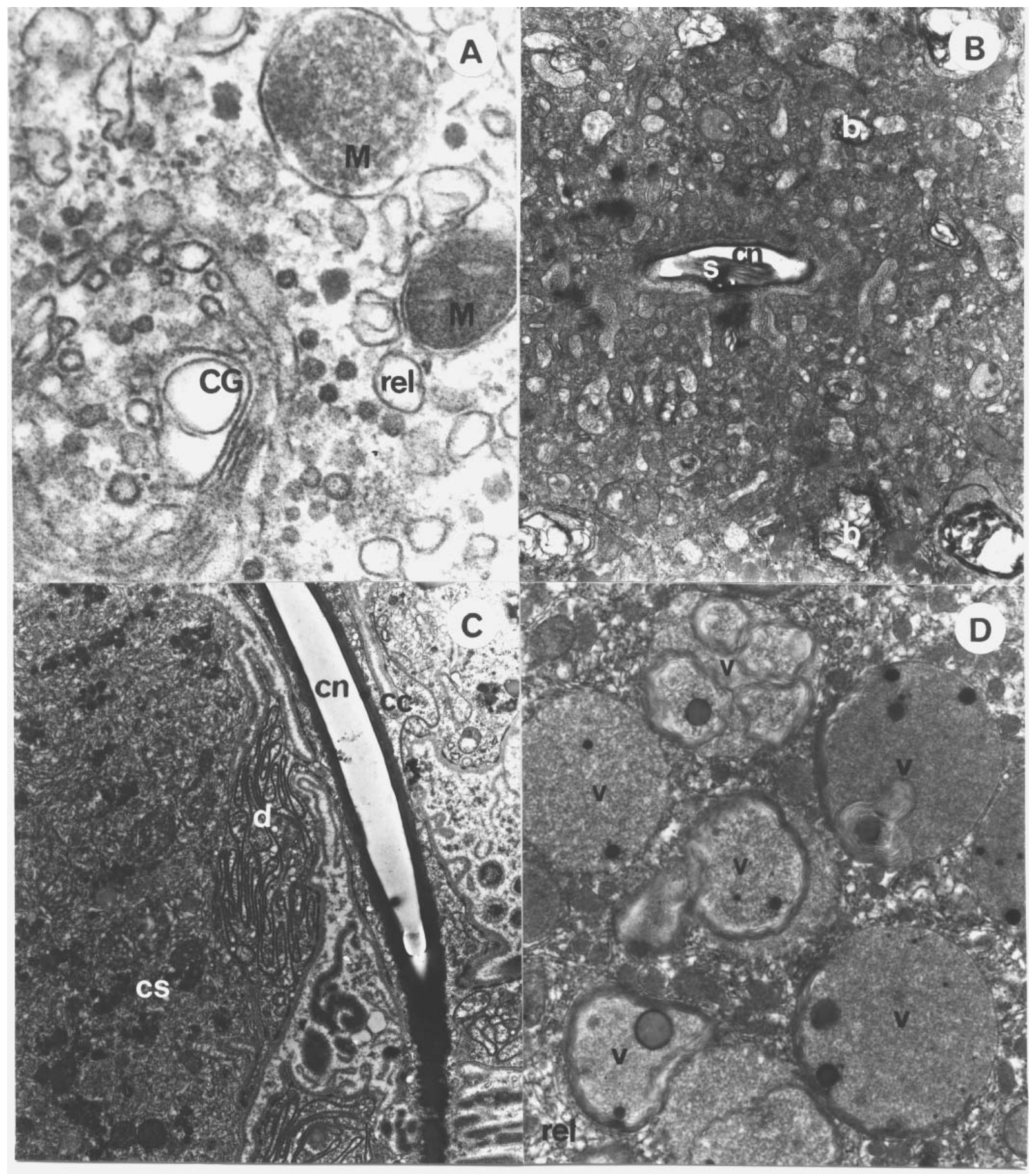

Figure 1. Transmission electron microscopy of mandibular glands. A. Cytoplasm of secretory cell $(\mathrm{x} 29,000)$. B. Cross section of canalicule into secretory cell $(\mathrm{x} 21,000)$. C. Contact between secretory cell and canalicule cell $(\mathrm{x} 9,500)$. D. Vesicle with secretion in the cytoplasm of secretory cell $(\mathrm{x} 21,000) . \mathrm{b}=$ myelinic body, $\mathrm{cc}=$ canalicule cell, $\mathrm{cs}=$ secretory cell, $\mathrm{CG}=$ Golgi complex, $\mathrm{cn}=$ canalicule, $\mathrm{d}=$ secretory cell plamic membrane fold, $\mathrm{m}=$ mitochondria, $\mathrm{rel}=$ smooth endoplasmic reticule, $\mathrm{s}=$ secretion, $\mathrm{v}=$ vesicle. 